\title{
Concept of Integrative Currency Area and Application to the Central Europe
}

\author{
Mieczysław Dobija \\ Faculty of Management, Cracow University of Economics, Cracow, Poland \\ Email: dobijam@uek.krakow.pl
}

How to cite this paper: Dobija, M. (2018) Concept of Integrative Currency Area and Application to the Central Europe. Modern Economy, 9, 1247-1261.

https://doi.org/10.4236/me.2018.97081

Received: June 21, 2018

Accepted: July 20, 2018

Published: July 23, 2018

Copyright $\odot 2018$ by author and Scientific Research Publishing Inc. This work is licensed under the Creative Commons Attribution International License (CC BY 4.0).

http://creativecommons.org/licenses/by/4.0/

\section{c) (i) Open Access}

\begin{abstract}
Euro zone is created along with theory of optimal currency area. This theory is not the only solution that indicates how to integrate countries in the common currency area. The euro area requires that labor productivity is at a similar level. Central European countries, on the other hand, have much lower labor productivity than Western European countries. The question arises about the possibility of creating a currency zone for countries with different levels of productivity. In this paper, it is indicated that there is a positive answer in this matter. However, this requires a rethinking and definition of the basic arrangement of the economic concepts. The paper indicates a method of translating economic values into value of the one currency. The main measurer limiting freedom is the labor productivity index, which cannot decrease what would cause inflation. The lower labor productivity means only that employees have the lower earnings.
\end{abstract}

\section{Keywords}

Currency Area, Labor Productivity, Translation, Monetary Unit

\section{Introduction}

Theory of optimal currency area is the supporting knowledge base of the European euro area. However, the euro area does not work fluently, and many doubts appear in respect to the theoretical foundations and applied procedures in conducting this project. In particular, the accession of new members is doubtful since euro area is clearly discriminatory and exclusionary to countries with productivity levels significantly lower than in the founding member states. Contrary to euro area here is presented consideration that develops an idea of integrative currency area (ICA). The ICA application in the Central Europe will work for real integration of countries. An additional aim of this paper is to point 
out how to involve states that do not fulfill the Maastricht criterion. The ICA can involve countries with different productivity levels that do not fulfill the Maastricht criterion. A significant part of this paper develops a measurement of labor productivity ratio as a chief economic measurer. The only condition of being a member of ICA is to hold the labor productivity not decreased.

What is more presented considerations may serve as an intellectual tool on a way to creation of union of countries belonging to $A B C$ area. The $A B C$ is an abbreviation where A means Adriatic Sea, B means Baltic Sea and C means Black Sea. An essence of this union in the Central Europe is creation a pole of strength equitable to Russia or Germany power. As Z. Sykulski has explained an aim of such project is protection from imperial temptations of the mentioned powers and creation of condition for free development of the nations of the region [1]. Confidence is growing now that the current geopolitical circumstances are unstable and will undergo changes. In this state of affairs, the Central-Europe countries should seek courses of action appropriate for the strengthening of sovereignty and the ways of entrance to the circle of countries of much significant in world politics.

\section{Fundamental Economic Concepts in the Theory of ICA}

In order to develop correct theory of the ICA a set of fundamental economic categories must be elaborated and precisely defined. It is necessary since in the development of economic thought one can see the amazing lack of continuity and consistency. In the fifteenth century already used the double entry accounting system, as a system measuring the periodic economic income of companies. In 1492, in Venice was printed book by L. Pacioli, in which he presented a theory of the double accounting system and its organization. The thing is that fundamental part of the accounting theory is the basic identity that contains the abstract categories of values, as capital and assets. This basic identity is a derivative of duality principle that allows for measuring periodic gains being an increase of the abstract capital invested by the owners. Thus, the abstract nature of capital could be well understood for at least 6 centuries. However notion of capital is still differently perceived [2] [3]. The latest example is the T. Piketty's book, in which the author presents its own tortuous term [4]. The author dedicates the Section 1.3 (p. 63-64) "What is capital?" and he underlines that he excludes what economists often call-by letter incorrectly- "human capital", that is, the power of work, qualifications, preparation, the ability of the individual. In opposition to this author we suggest that capital must be perceived as abstract ability of doing work. Then T. Piketty introduces his own point of view about category capital defining it as all of the assets, which may be held and exchanged on the market. So capital includes particularly all the real estate (buildings, houses) used for housing and financial and organizational capital as buildings, equipment, machinery, patents, etc. used by companies and administrations.

It follows that the author (perhaps unconsciously) does not respect the 
achievements of the theory of the double accounting and the principle of duality that points on the abstract nature of capital. He does not perceive the importance of this knowledge for the existence and functioning of money-goods economy. This attitude is not unique among economists, which does not mean that is universal, but is, however, a little reflective. But the point is that the lack of understanding the strong relationship between capital and labor has a negative impact on the quality of the economic analyzes and conclusions.

It looks like W. Piketty confirms K. Bliss (1975) opinion about confusion with category of capital who wrote that when economists reach agreement on the theory of capital they will shortly reach agreement on everything [5]. Abstract nature of capital is explained long ago and applied to important theoretical formulation by M. Dobija and B. Kurek [6] [7]. Authors interpret capital as abstract potential ability of doing work. What is more an economic constant of potential growth is discovered. It is worth noting that abstract categories, which are defined and measured in the physical sciences or accounting systems must be described and analyzed mathematically. It is therefore natural that well versed scholars in mathematics wrote papers on accounting like L. Pacioli and even Professor of pure mathematics A. Cayley [8], the author of the basic theorems in the theory of analytic functions.

The set of economic categories that forms fundamentals for accounting and economic of labor are a consequence of the duality principle. As is explained in paper by M. Dobija [9] the duality means that different sorts of assets embody abstract capital that express ability of the assets to work. Assuming that economic means denotes a prime notion that does not require explanations the fundamental set of categories is presented in the body of Table 1 .

The above set of notions is a fundamental of economics of labor. In order to grasp the idea of capital we have to notice the tandem of capital and labor. That tandem is a direct implication from the definition of capital. Capital is the ability of doing work. It is therefore the potential for doing work (e.g. the car in a garage). Labor process on the other hand is a transfer of this potential of accumulated capital to objects of work. Thus labor is a dynamic side of the potential capital. One cannot perform any labor without having capital that was collected earlier. Therefore labor determines also a unit of measure of capital.

It is hard to explain why the above understanding of these significant categories did not become a standard for economic thinking through ages. Capital by definition is closely related with labor and value. The work is measurable so it assures a measurability of capital and assets. Money is a work receivable, namely regardless law to obtain value equivalent, and this category is also abstract although so much popular. Why such a long-lasting difficulties exists, despite L. Pacioli [10] published his book, in which appears an abstract category of capital and the basic double-entry equation. The purpose of this accounting system was, and still is, a periodic measuring of increase of the initial capital invested in the economic processes, i.e. income. Moreover, the use of the double-entry accounting soon became the norm, and economic history researchers [11] wrote 
Table 1. The set of fundamental economic notions.

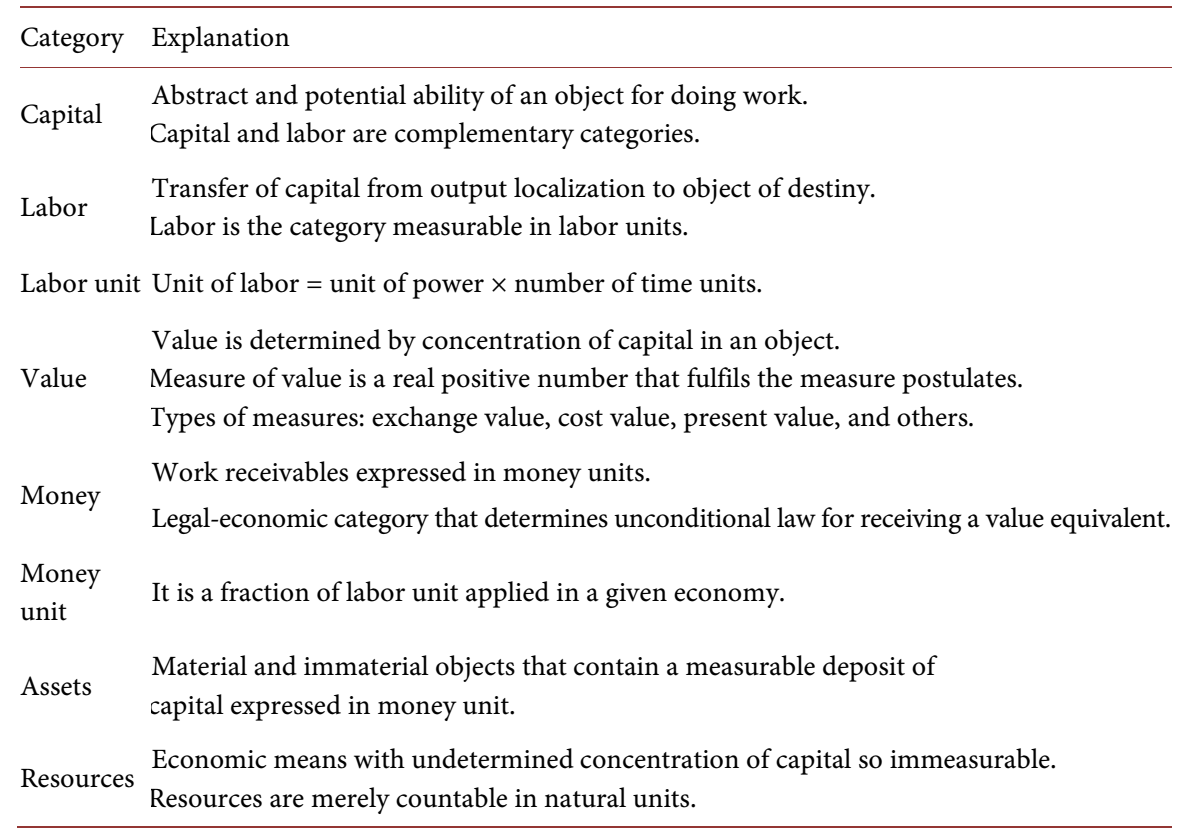

very positive opinions about the contribution of this system for the development of capitalism.

\section{Labor Productivity as the Fundamental Economic Measurer}

Having defined the set of fundamental notions concept of labor productivity should be taken under consideration. To this aim a special kind of description of economic activities is needed. A significant tool of economic consideration is the well known production function. It is however the tool limited to examining of the production process. The theory of production function examines and explains the general production process not a specific entity. What is more the econometric modeling needs statistical approach and sets of data. Therefore for the construction of ICA the concept of the production function needed some rethinking. As a result a mathematical description of the economic activity of the economic entity (company or state) has been created. In this approach the function of economic activity (FEA) takes into account the value of assets as well value of human capital of employees. The FEA leads directly to labor productivity ratio $Q$. If considered entity is a state so FEA presents $G D P=W \times Q$ that is equal to the factor $W \times Q$ ( $W$ - total remunerations). In the economics of laborit is natural that the tandem $(G D P, Q)$ is the main measure of economic evaluation.

From other point of view the quotient of market value of final annual products of an organization to annual cost of labor is a specific dimensionless ratio called labor productivity. Denoting it as $Q$ we speak about labor productivity of a country economy $Q=G D P / W$, where $W$ denotes the cost of labor. Then the $Q$ is the inverse value of well known ratio of labor share. Since labor share is very 
stable the $Q$ is stable as well. We can write an identity including $Q$, which sheds new light on the issue of the share of wages in GDP. The identity proves that $G D P$ is a sum of the share of wages $(W)$ and the share of assets $\left(G D P_{A}\right)$. The greater is the assets share the wealthier is a country.

$$
G D P=G D P \frac{1}{Q}+G D P \frac{Q-1}{Q}=W+G D P_{A}
$$

The FEA expressed analytically may be a tool of economic analysis or it may provide numerous non-linear models describing the behavior of a selected variable. The value of final production sold in the historical prices of outlays may be expressed as follows:

$$
G D P=K(1+Z / K)
$$

where: $K$-all costs of manufacturing and managing, and $Z$-annual income. Thus $Z / K$ denotes cost profitability. This ratio can be introduced as a function of the $R O A$. The quotient $w=K / A$, where $A$ is the book value of assets that is known as the turnover ratio. Thus $K=w A$ so $Z / K=Z / w A=R O A / w$.

Considerations of the FEA show that the $Q$ can be interpreted as follows [12]:

$$
Q=\frac{G D P}{W}=\mathrm{e}^{r}\left[1+\frac{A}{H} \times \frac{z}{u}\right] \approx \mathrm{e}^{\frac{A F}{W}}
$$

where: $W$-cost of labor, $A$-end of period value of assets, $r$-cost profitability, $z$-turnover ratio, $u$-percentage of pay in respect to employees human capital $H$, $F$-level of management and $F=F(r, z, u)$.

The FEA is a kind of function that takes into account the criticism of the econometric modelling of production expressed by J. Robinson [13]. Arguments of the FEA represent economic value, which is the measure of embodied capital. Therefore the $Q$ is present in the most significant economic explanation and among others a trend of the exchange rate, which is discussed in more detail by M. Jędrzejczyk [14]. An important application of the $Q$ is the wage equation of exchange that determines a required level of credit in the money-goods economy [15].

\section{Integrative Currency Area versus Euro Area}

Theory of the ratio $Q$ allows discussing agenda of the integrative currency area (ICA) versus euro currency area. The formation of the ICA requires of solving a problem how to implement one money unit in countries with different labor productivity as Poland and neighbouring countries? In such a case an employee working in Hungary for example will directly buy goods in Poland for his native earnings and vice verse. This task seems simple; it is enough to change name of Polish and Hungarian money unit to common one. If at the moment Hungary has greater labor productivity and compensation is higher so Hungarian citizens have greater purchasing power in Poland. Polish citizens can enjoy higher demand and opportunity for faster development. Poland cannot in return raise wages since labor productivity ratio should not decline but process of economic 
equalization has already started. By the tight control of labor productivity the ICA is an answer for question how to construct a stable currency area with ability of integrating subsequent members. Then, only one money unit would rule in this area without any exchange rate. This is also a way to global currency area under condition of reshaping of the central bank function.

Countries have their own economic systems including work remuneration. What's more each country has its own level of labor productivity. The fundamental condition of ICA organization is maintaining (not declining) the ratio $Q$. A growth of this ratio is highly appreciated. The ratio $Q$ is the most significant indicator for organization and conducting the ICA. A currency area is integrating zone provided is able to accept countries with different ratio $Q$. Each country can be accepted to the ICA provided as a member of ICA is able to maintain or eventually to increase the $Q$. Therefore not declining the $Q$ is the indispensable condition of membership. Decreasing the $Q$ means growing inflation; so wages are too high. Increasing the $Q$ means that employees may eventually got a rise.

Difficulties that are an experience of the EU rely on a different level of labor productivity, and of course existence of European Central Bank operating under a fault theory. The euro, as commonly known, was introduced at the beginning of 1999 , fully since 2002, when there was a delegation of competence in the field of the single monetary policy to the European Central Bank. The 11 member states were joined in 2001 by Greece and in 2007 by Slovenia. On $1^{\text {st }}$ January 2008 two countries joined the euro area: Malta and Cyprus. While creating the euro area in countries where $Q>3.0$ was justified by an almost equal and high labor productivity (assessment based on the situation in 2006), joining the Eurozone by countries with a productivity of approximately 2.5 is questionable, and with $Q$ less than 2.0-inappropriate. This partition shows that Europe has several "speeds". Polish politicians do not want to belong to the Europe of the second speed, but their words are really just a form of putting a spin on reality.

Currency areas can be created based on the current economic theory, as described by various prominent authors, adopting an independent central bank and its functions as the canon of economics. The most renowned author is $\mathrm{R}$. Mundell [16], whose examples of creating a currency area (division of the North American continent into East and West), illustrating the theory of optimum currency areas, have long been capturing the imagination of many scholars. It is a fact that the euro area has been formed based on a group of economically homogeneous countries $(Q>3.3)$, which is why it was so successful at the beginning. The problems with Greece, Portugal and other South countries with the $Q$ $<2.3$ are caused by the much lower labor productivity in these countries. In such a country a free exchange rate is a market regulator that helps to keep economic balance. This regulator is set off and does not work in the euro area.

Euro area requires the real economic sphere to achieve certain, determined by theory, parameters with respect to inflation, exchange rate behavior and productivity. That is why the current Euro zone does not integrate all European countries. What is more membership is not helpful in speeding up economic integra- 
tion. On the contrary, euro area is clearly discriminatory and exclusionary with respect to countries with productivity levels significantly lower than in the founding member states. These latter, with a similar level of labor productivity, were already economically integrated, so creating the euro area was a natural, formal undertaking. The difficulties started when countries with a lower rate of productivity were being included. These difficulties are enormous and insurmountable in the short term.

\section{Translation of Wages to Common Monetary Unit}

Creating the ICA requires a reorganization of central bank tasks and a proper translation of wages. The central bank no longer emits money by fiat but it pays compensations for public sector employees [17]. Then the main issue is the adjustment of wages to the value of a new monetary unit. In application of the theory of translation, there must be clearly defined measurable quantities in the statistical office of each country. Necessary, clear interpretations of every variable are necessary. The conversion method consists in using the values expressed in the national currency of: GDP and GDPE, or GDP per one employed. Parities of these values are taken into account. The starting point is the natural dependence:

$$
G D P=W \times Q=W \times Q \times(L / L)=S \times Q \times L
$$

where: GDP-real value of GDP, $W$-sum of compensations (labor costs), $Q$-real labor productivity, $L$-number of employees, $S$-average cost of labor.

Let the index $\mathrm{M}$ denote the selected country with a conversion factor equal to 1.0 which will be the reference for ABC. Basic economic values will be adapted to it. For this purpose, it is worth indicating the appropriate country, for example Slovakia, whose monetary unit is the euro. It is assumed that the P index means Poland and the $\mathrm{M}$ index denotes Slovakia as a model country. Two equations are created:

Model country: $G D P_{M}=S_{M} \times Q_{M} \times L_{M}$

Poland: $G D P_{P}=S_{P} \times Q_{P} \times L_{P}$

Dividing the equation for Poland by the equation with the index M, we obtain:

$$
\frac{G D P_{P}}{G D P_{M}}=\frac{S_{P}}{S_{M}} \times \frac{Q_{P}}{Q_{M}} \times \frac{L_{P}}{L_{M}}
$$

Now the above formula is reshaped and the average pay parity is computed:

$$
\frac{S_{P}}{S_{M}}=\frac{G D P_{P}}{G D P_{M}} \times \frac{Q_{M}}{Q_{P}} \times \frac{L_{M}}{L_{P}}=\frac{G D P E_{P}}{G D P E_{M}} \times \frac{Q_{M}}{Q_{P}}
$$

where: GDPE-denotes real GDP per employee. It appears that this parity is a product of the two parities namely variables $Q$ and $G D P E$.

Computing coefficient $D=\frac{G D P E_{P}}{G D P E_{M}} \times \frac{Q_{M}}{Q_{P}}$ we obtain coefficient for translating of compensations. Therefore translation formula is as follows ( $E$ is name of money unit in the ISW): 


$$
S_{M}[E]=S_{P}[P L N] / D[P L N / E]
$$

This formula leads to equivalent value of earnings. To illustrate computations, below is presented translation of compensations for a group of countries. In the calculations, Slovakia was chosen as the model country, whose currency is currently the euro, so there is a common understanding of the value of this unit. Of course, after the creation of $\mathrm{ABC}$, the original name of the currency will be entered. Temporarily, the unit of the $\mathrm{ABC}$ currency is denoted by the letter $\mathrm{E}$. Table 2 presents a selected set of countries, future members of $A B C$, and contains basic quantities from databases. The last column contains the calculation of the indicator $\mathrm{Q}$.

Table 3 presents the main results of calculations, that is, the determination of the compensations conversion rate and the determination of wages on the assumption that Slovakia is a model country.

Table 3 gives information that Polish wages and assets at the beginning of 2017 should be divided by 3.826 , when the euro exchange rate is currently 4.19 PLN. What positively surprise are the similar values of the calculated wages of the $\mathrm{ABC}$ states. However, this is natural. Workers such as construction workers, transport workers, teachers, police officers, and civil servants, mostly carry out similar work in similar conditions, generating GDP measured in national currencies. Avoiding adulteration of the economic image by the crude application of exchange rates for the conversion of wages, the calculations show the existence of favorable conditions for the creation of a common currency area in the Central East Europe.

A subsequent important agenda of every country is a system of compensation for labor. There are many reasons to pay attention to wages but in the case of the

Table 2. Basic data for computing coefficient D. 2016 year.

\begin{tabular}{|c|c|c|c|c|c|}
\hline Country & GDP & $\begin{array}{c}\text { Number of } \\
\text { working person } \\
1000 \mathrm{~s}\end{array}$ & $\begin{array}{c}\text { Average } \\
\text { pay per year }\end{array}$ & $\begin{array}{c}\text { Employer } \\
\text { additional } \\
\text { payment }\end{array}$ & Q \\
\hline Slovakia & 80,847 bin $\mathrm{E}$ & 2321 & $12,596 \mathrm{E}$ & $18 \%$ & 2.33 \\
\hline Poland & $1865.69 \mathrm{bin}$ & 16,061 & 47,919 PLN & $19 \%$ & 2.04 \\
\hline Czech R. & 4631.99 bin & 5273 & $331,985 \mathrm{~K}$ & $21.5 \%$ & 2.17 \\
\hline Hungary & 32211.44 bin & 4403 & $3,112,305 \mathrm{~F}$ & $18 \%$ & 1.99 \\
\hline Croatia & 342,065 bin HRK & 1579 & 72,264 HRK & $32.2 \%$ & 2.27 \\
\hline Romania & 754,411 bin $\mathrm{ROL}$ & 4824.4 & $39,492 \mathrm{ROL}$ & $38.5 \%$ & 2.87 \\
\hline Bulgaria & 88,525 bin BGL & 3036.7 & 12,432 BGL & $21 \%$ & 1.94 \\
\hline Serbia & 4147 bin CSD & 2652.2 & 49,635 CSD & $30 \%$ & 2.03 \\
\hline Belorussia & 97,042 bin $\mathrm{BR}$ & 4366.7 & $9542.4 \mathrm{BR}$ & $23 \%$ & 1.89 \\
\hline Ukraine $^{*}$ & $23,831,826 \mathrm{mln} \mathrm{UAH}$ & 17,955 & $62,196 \mathrm{UAH}$ & $22 \%$ & 1.75 \\
\hline
\end{tabular}

*Date from State Statistics Service of Ukraine (http://www.ukrstat.gov.ua). Sources: Economic Indicators: GDP (Current Prices, National Currency) 2016, The Conference Board Total Economy Database ${ }^{\mathrm{T} \mu}$, May 2017, https://tradingeconomics.com/indicators. 
Table 3. Coefficient D and translation of wages.

\begin{tabular}{ccccccc}
\hline Country & Q & GDPE & $\begin{array}{c}\text { Parity of } \\
\text { PKBE }\end{array}$ & $\begin{array}{c}\text { Parity of } \\
\text { Q }\end{array}$ & $\begin{array}{c}\text { Exchange rate } \\
\text { of translation D }\end{array}$ & $\begin{array}{c}\text { Pay } \\
{[\mathrm{E}]}\end{array}$ \\
\hline Slovakia & $\mathbf{2 . 3 3}$ & $\mathbf{3 4 8 3 3 €}$ & 1.00 & 1.000 & 1.000 & 1050 \\
Poland & 2.04 & $116,163 \mathrm{PLN}$ & 3.35 & 1.142 & $3.826[\mathrm{PLN} / \mathrm{E}]$ & 1044 \\
Czech Rep. & 2.17 & $878,435 \mathrm{CZK}$ & 25.22 & 1.074 & $27.086[\mathrm{CZK} / \mathrm{E}]$ & 1021 \\
Hungary & 1.99 & $7,315,794 \mathrm{HUF}$ & 210.02 & 1.171 & $245.933[\mathrm{HUF} / \mathrm{E}]$ & 1055 \\
Croatia & 2.27 & $216,634 \mathrm{HRK}$ & 6.22 & 1.026 & $6.382[\mathrm{HRK} / \mathrm{E}]$ & 944 \\
Romania & 2.87 & $156,374 \mathrm{ROL}$ & 4.49 & 0.812 & $3.646[\mathrm{ROL} / \mathrm{E}]$ & 902 \\
Bulgaria & 1.94 & $29,152 \mathrm{BGL}$ & 0.837 & 1.201 & $1.005[\mathrm{BGL} / \mathrm{E}]$ & 1031 \\
Serbia & 2.03 & $1,563,608 \mathrm{CSD}$ & 44.9 & 1.148 & $51.53[\mathrm{CSD} / \mathrm{E}]$ & 963 \\
Belorussia & 1.89 & $22,223 \mathrm{BNR}$ & 0.638 & 1.233 & $0.7865[\mathrm{BNR} / \mathrm{E}]$ & 1011 \\
Ukraine & 1.75 & $132,731 \mathrm{UAH}$ & 3.81 & 1.331 & $5.0711[\mathrm{UAH} / \mathrm{E}]$ & 1022 \\
\hline
\end{tabular}

Sources: Economic Indicators: GDP (Current Prices, National Currency) 2016, The Conference Board Total Economy Database ${ }^{\mathrm{nt}}$, May 2017, https://tradingeconomics.com/indicators.

ICA authorities have particular responsibility because of necessity of labor productivity control. Theory of human capital measurement and fair compensation for labor determines wages as percent of employee's capital [18]. What percent? This percent is equal to the rate of spontaneous and random rate of human capital dispersion s. General model of capital explains that mean value of the random variable $\mathrm{s}$ is equal to the constant $\mathrm{p}$, i.e. $\mathrm{p}=\mathrm{E}(\mathrm{s})=0.08$ [1/year] [19]. Using this relation the fair compensation take into regard formula $\mathrm{W}=\mathrm{p} \times$ $H(p)$, where: $p=0.08$ and denotes constant of potential growth, $H(p)$-denotes employee's human capital, $\mathrm{W}$-fair remuneration.

To illustrate let us consider theoretical minimum wage. From the theoretical (not legal) point of view such a pay is relevant to teenager 17 or 18 years old who start with his first job. Human capital of such a worker includes neither capital of professional education nor experience capital. This value represent only capitalized cost of living. Poland is a country that strives to achieve $100 \%$ of consistency of theoretical and legal minimum wage. Therefore legal minimum wage for 2018 year is determined as 2180 PLN so that cost of labor estimates $2180 \times 1.2$ $=2616 \mathrm{PLN}$. Thus percent of consistency to the legal minimum pay attains to $93 \%$. This would be a success provided cost of living was constant. Empirical research shows that level of consistency $C$ depends on labor productivity $Q$ [12]. Presently, in line with J. Renkas [20] this relation is described by formula:

$$
C=73.89 \times Q-10.89 \times Q^{2}-21.80
$$

Assuming that the $Q$ for Poland will be 2.10 in 2018 year, so the $C=85.34 \%$. Thus, the legal minimum wage for 2018 can be slightly too high for Polish economy. But it is a choice. A country can strive for increasing the $Q$ or to increasing remunerations. 


\section{Inflation-Deflation Agenda}

Another essential problem of forming the ICA is inflation-deflation agenda. Problem of inflation is already theoretically solved by restriction on labor productivity. By definition the $Q=G D P / W$ so the condition of not declining $Q$ means that compensations must be controlled and limited. Size of credit is also under control as it has been discussed in the above cited paper. Deflation however still needs discussion. As is commonly known deflation is falling consumer price index so deflation occurs when the general level of prices falls. R. Bootle [21] points that in Japan "downward trend of consumer prices has meant that consumer price level in 2003 is the same as it was a decade earlier". It is obvious that increasing of labor productivity can lead to falling prices. Therefore some economist draws distinction between "bad deflation" and "good deflation". This classification is not a canon since increase of labor productivity usually leads to rise of wages so deflation should not happen. A press on rise of wages usually exceeds labor productivity growth.

Deflation could be seen as a normal phenomenon in developed countries working under monetary paradigm. Let us assume that a country has a fair system of work compensation. Fair employee's earnings are taxed so their real earnings become unfair (too small). They do not generate enough demand and many economic troubles come to existence. Then the Say's law is bringing to a halt. In the ICA taxation concerns this part of salaries which exceeds the fair level. The Central Bank is the payer of remuneration for the public sector employees so this stream of money does equalize stream of value embodied in products and services. Deflation cannot come to existence but inflation is under control by the ratio $Q$. The Say's law acts correctly. Among members of the ICA there are not countries that finance their budgets by disproportionate emissions of money (it is impossible), without a close relationship with economic performances.

Money-goods economy needs credit. This agenda is elaborated earlier [22] and a formula that determine necessary amount of credit is as follows:

$$
\text { Credit }=W \times(Q-a-d)
$$

The above formula explains that the needed credit depends on: labor cost stream $W$, and the real work productivity $Q$. The credit is declined by the poverty level (a) as well changes in savings and detriment funds (d). An employee is discerning as poor if he or she does not have any savings. The greater is the productivity of work (depending strongly on the value of assets) the greater are the possibilities and requirements of crediting. The above formula indicates only main macroeconomic variables, which have impact on the requirements of generating credit by commercial banks. Apart from these variables there is a set of constraints needed for providing safety of a commercial bank, which seriously limits lending.

Thus the key explanation of deflation lies in drawbacks of monetarism and incorrect function of the central banks in economy. The right remedy is eco- 
nomics of labor as discussed in many earlier papers [23] where the central banks is the payer of remuneration to public sector employees (PSE)and the taxes are low.

\section{Making the $A B C$ Union Work}

How to make the $\mathrm{ABC}$ Union work is a following question. It is worth noting that the creation and development of the ICA is not necessarily an equivalent to total freedom of movement for the population. An agreement about free movement between countries is not a mandatory requirement of the ICA formation. The ICA is an economic tool to strive for a welfare state, which can be achieved by wise, hardy, and productive labor with the help of an encouraging international environment. But the countries can by bilateral agreements to establish free movement of peoples. The ICA is free from the exchange rates and all the intellectual challenges related to them, such as the exchange rate movement and policy. The introduction of the ICA must be accomplished step by step that are roughly described in Table 4 . Here CB, LP, MU denote respectively central bank, labor productivity, and the $\mathrm{ABC}$ area monetary unit.

The first step relies on implement by a country a new financial system with the purpose of be able to use the self-financing of labor for the PSE. This means that main task of the central banks changes to be payers for PSE and cash money emissions no longer exist. Then the country experiences many benefits such as a lack of budget deficits and the possibility of taxes declining. The second step starts at the end of negotiations for the treaty of the political agreement of creating the ICA i.e., relinquishing the exchange rates applied during economic

Table 4. The set of fundamental directives that determine way of conducting ICE.

\begin{tabular}{|c|c|c|}
\hline \multicolumn{2}{|c|}{ StepDescription } & \multirow{2}{*}{$\begin{array}{l}\text { Explanation } \\
\text { The High Council is responsible for ABC supervising } \\
\text { and conducting. They admit new member. }\end{array}$} \\
\hline 1 & $\begin{array}{l}\text { The High ABC Council begins } \\
\text { operation }\end{array}$ & \\
\hline 2 & $\begin{array}{l}\text { Reform of the CB. Introduction of } \\
\text { procedures of LP control }\end{array}$ & $\begin{array}{l}\text { Introduction of legal act changing functions of CB to be } \\
\text { payer of remuneration for PSE. CB becomes LP } \\
\text { controller. Emission of money is eliminated. }\end{array}$ \\
\hline 3 & Selection of model country & Determination of name of $\mathrm{MU}$ in the $\mathrm{ABC}$. \\
\hline 4 & Access of a second country & Evaluation of LP. Applying the translation procedures. \\
\hline 5 & Edition a directive on minimum wage & Adjusting the minimum wage to theory of fair pay. \\
\hline 6 & $\begin{array}{l}\text { Edition a directive on labor } \\
\text { productivity control }\end{array}$ & $\begin{array}{l}\text { Introduction procedures how to measure a level of labor } \\
\text { productivity among the ABC members. }\end{array}$ \\
\hline 7 & Edition a directive on credit control & $\begin{array}{l}\text { The credit formula is a part of theory of wage equation } \\
\text { of exchange. }\end{array}$ \\
\hline 8 & $\begin{array}{l}\text { Edition a directive on control of } \\
\text { exchange rate with outer world }\end{array}$ & $\begin{array}{l}\text { The parity of labor productivity ratio is the chief } \\
\text { determinant of the fair exchange ratio. }\end{array}$ \\
\hline 9 & $\begin{array}{l}\text { Edition a directive on control of } \\
\text { commercial bank liquidity and } \\
\text { solvency }\end{array}$ & $\begin{array}{l}\text { Central Bank no longer emits money so commercial } \\
\text { bank must maintain liquidity and solvency on its own. } \\
\text { Procedures ought to be precise and effective. }\end{array}$ \\
\hline
\end{tabular}


exchanges. This agreement, signed for example by Poland and Hungary, contains the decision to introduce the one currency unit $\mathrm{MU}$ and the translation compensations and value of assets to the new currency unit. If the free movement of people are maintained citizens of both countries can buy and pay in MU. Reformed CB of each country cannot issues money so only market forces will determine exchange rates between MU and euro or dollar .Next step starts when other countries are ready to access to ICA. They have to pass an audit organized by High Council with positive opinion.

What sort of costs and benefits appear if any country becomes a member of the ICA? It is hard to show any costs besides some political. In contrast, the benefits are numerous and offer great value. Despite the abolition of money emission by the CB countries would gain tax-less financing of the PSE that produces billions of MU per year-at least $25 \%$ of total compensations. Of course, the control of labor productivity would have to be tightened in order to have constant value or growth of the $\mathrm{Q}$ ratio. Then country enters on the way to a group tending to the best developed states. The most economic benefits are related to introduction of labor self-financing and the abolition of the exchange rate in inner economy of the ICA. It changes the debt economy that presently works as engines driven by debts [24] to a normal economy, where a budget deficit is an extraordinary event that may point to bad management or enormous military expenses.

The ICA is also an indicator of right way to real globalization. The present views on globalization are described by many authors, of whom the best known is J. Stiglitz [25]. It is hard to add anything to this author's precise analysis, but it is essential to share his diagnosis. It is also clear that the vision of globalization created by J. Stiglitz still needs a correct solution of one essential agenda, namely the problem of the reserve money system. Neither artificial money with a peculiar name is a remedy for the reserve money system, but rather a common acceptance of the view that money arises as a consequence of labor. Assuming this scientific point of view, money is an abstract category related to capital and labor. Money arises as an accounting record of labor receivable.

Globalization is a vital process for world progress in both economic and political dimensions. It is evident that global economy requires a correct theory, and here is the problem. As J. Stiglitz's analysis shows, at the beginning of the nineties globalization was welcomed with the hope of progress and a better future, but less than two decades later, serious protests have appeared. Presently, globalization is often connected with dark forces. The global economy needs a strong, correct theory, and honest political willpower. These attributes cannot be replaced by military force and political domination. Flaws of economics and, in particular, an inadequate theory of money are well known and hotly debated by many authors [26]. Regardless of this confusing situation, the monetarists still maintain that money is simply a product and then they manufacture cash money from nothing, contaminating natural flows of capital and value in economies. They do not bother with contradictions. 


\section{Summary and Some Ending Remarks}

At this study, algorithms for translating remuneration for work into a common monetary unit introduced in the integrating currency area are presented. The course of proceedings in organizing and implementing the operation of the currency area was also indicated. ICA is a consequence of economic thought referring to the labor economy, which in effect changes the economic system for better. The money-goods economy is a great achievement under condition that the triad: capital-labor-money is completely recognized and respected. Then human capital becomes a means of increasing value; that is to say, for creating well-being.

The integrative currency area concept yields insight into the duality of capital and labor. It reveals the self-financing of labor and brings to light new possibilities of a money-goods economy. An economy without a budget deficit and rectified income tax is a real perspective. But the integrative currency area leads in the final effect to a global currency area; that is to say, to a world with new qualities and more hopes that globalization will lead to peaceful coexistence and balanced development. In this project, the future world is without a reserve currency system. J. Stiglitz and B. Greenwald [27] introduced precise analysis conducted in the old financial framework with an opinion that "... a new global reserve system is absolutely essential, if we are to restore the global economy to sustained prosperity and stability. But achieving this, too, will not be easy...”. In a world with merely one currency, a government will likely hold surplus money in a portfolio of bonds of different countries, taking care of liquidity and gaining additional earnings.

Therefore, the correct solution of the reserve currency agenda would be the introduction of the ICA worldwide, which would have only one money unit, and the problem of reserve currency would no longer exist. An individual doing the same job would earn different monthly pay in dissimilar countries. In a poor country it could be, let us say, $200 \mathrm{MU}$, in Poland it could be $750 \mathrm{MU}$ but in the USA it could reach $1300 \mathrm{MU}$. But the process of convergence is already set into motion. Each country would enjoy a better future, without the danger that the authorities would establish a crazy exchange rate, for example "one peso for one dollar" or "thirty UAH for euro" since they introduce so called "liberal reforms".

Poland and others Central Europe countries have no sources of power as far says J. Bartosiak [28], well known Polish geopolitician. Poland should strive to form some source of power reforming architecture of Polish space, tending to open ways for trade from North to South by Slovakia and Ukraine among others. The presented consideration shows that Poland could be a designer of the ICA in the Central Europe and together with group of neighboring countries to become a centre of force and decisions. In my belief union of countries with economy without budget deficit, with taxes limited to financing assets mainly, attracts thoughtful attention of the world, whereas building an organization against other nations is unstable and unreliable basis for future geopolitical organization. 


\section{References}

[1] Sykulski, L. (2015) Polska myśl geopolityczna w latach 1989-2009. [Polish Geopolitical Thought in the Years 1989-2009.] Chorzowskie Towarzystwo Naukowe, Chorzów, 247.

[2] Kurek, B. (2011) Hipoteza deterministycznej premii za ryzyko. [The Deterministic Risk Premium Hypothesis.] Wydawnictwo Uniwersytetu Ekonomicznego w Krakowie, Kraków.

[3] Kurek, B. (2011) An Estimation of the Capital Growth Rate in Business Activities. Modern Economy, 3, 364-372. https://doi.org/10.4236/me.2012.34047

[4] Piketty, T. (2015) Kapitał w XXI wieku. [Capital in the 21st Century.] Wydawnictwo Krytyki Politycznej, Warszawa.

[5] Bliss, Ch. (1975) Capital Theory and the Distribution of Income. North-Holland Publishing, Oxford.

[6] Dobija, M. and Kurek, B. (2013a) Scientific Provenance of Accounting. International Journal of Accounting and Economics Studies, 1, 16-24. https://doi.org/10.14419/ijaes.v1i2.1054

[7] Dobija, M. and Kurek, B. (2013b) Towards Scientific Economics. Modern Economy, 4, 293-304. https://doi.org/10.4236/me.2013.44033

[8] Cayley, (1894) Principles of Book-Keeping by Double-Entry. Cambridge University Press, Cambridge

[9] Dobija, M. (2016) Układ pojęć konstytuujących teorię rachunkowości w kontekście nauk ekonomicznych. [A System of Concepts Constituting the Theory of Accounting in the Context of Economic Sciences.] Zeszyty Teoretyczne Rachunkowości, tom, 89, 9-28.

[10] Pacioli, L. (1494) Summa de arithmetica, geometría, proportioni et proportionalità. P. de Paganini, Wenecja, Vinegia.

[11] Rosenberg, N. and Birdzell, L.E. (1994) Historia kapitalizmu. [The History of Capitalism.] Signum, Kraków, 181-186.

[12] Dobija, M. (2011b) Labor Productivity vs. Minimum Wage Level. Modern Econo$m y, 2,780-787$.

[13] Robinson, J. (1953-1954) The Production Function and the Theory of Capital. Review of Economic Studies, 21, 81.

[14] Jędrzejczyk, M. (2012) Labor Productivity Parity vs. Trend of Exchange Rate. Modern Economy, 3, 780-785.

[15] Dobija, M. (2011a) Abstract Nature of Money and the Modern Equation of Exchange. Modern Economy, 2, 142-152.

[16] Mundell, R. (1968) International Economics. Macmillan, New York, 177-186.

[17] Dobija, M. (2005) Financing Labor in the Public Sector without Tax Funds. Argumenta Oeconomica Cracoviensia, No. 4.

[18] Renkas, J. (2012) Empirical Test of the Human Capital Model and Minimum Wages. Nierówności Społeczne a Wzrost Gospodarczy, Zeszyt 24, 180-191.

[19] Dobija, M. (2015) Laborism. The Economics Driven by Labor. Modern Economy, 6, 578-594. https://doi.org/10.4236/me.2015.65056

[20] Renkas, J. (2016) Labor Economics: The Theory of Fair Remuneration. Prace Naukowe Uniwersytetu Ekonomicznego we Wrocławiu, $\mathrm{Nr} 439$, 284-301. https://doi.org/10.15611/pn.2016.439.25 
[21] Bootle, R. (2003) Money for Nothing: Real Wealth, Financial Fantasies and the Economy of the Future. Nicholas Bearley Publishing, 71-100.

[22] Dobija, M. (2016) Laborism and the Economics of Limited Taxes. Argumenta Oeconomica Cracoviensia, No. 14, 29-58. https://doi.org/10.15678/AOC.2016.1402

[23] Dobija, M. (2012) Political Reform Based on a Human Capital Research Program. Argumenta Oeconomica Cracoviensia, No. 8, 9-29.

[24] Rushkoff, D. (2006) Open Source Currency. In: Brockman, J., Ed., What Is Your Dangerous Idea, Edge Foundation, Smak Słowa, Sopot, 244-245.

[25] Stiglitz, J. (2007) Making Globalization Work. Polish Edition, PWN, Warsaw.

[26] Davar, E. (2011) Flaws of Modern Economic Theory: The Origins of the Contemporary Financial-Economic Crisis. Modern Economy, 2, 25-30. https://doi.org/10.4236/me.2011.21004

[27] Stiglitz, J. and Greenwald, B. (2010) Towards a New Global Reserve System. Journal of Globalization and Development, 1, 1-22. https://doi.org/10.2202/1948-1837.1126

[28] Bartosiak, J. (2014) The Polish Road from Weakness to Strength. Nowa Konfederacja. http://blogpress.pl/node/20374 